\title{
Monitoring Diffusion of Industrial Innovations and Cashless Society Infrastructure for Economy 4.0
}

\author{
Magdalena Lestari Ginting ${ }^{1}$, Finsensius Yuli Purnama ${ }^{2}$, Mesti Woro Mahatmi ${ }^{3}$ \\ \{magdalena.ginting@uph.edu ${ }^{1}$, finspurnama@ gmail.com ${ }^{2}$, florentina.mesti@gmail.com ${ }^{3}$ \} \\ Pelita Harapan University, Tangerang ${ }^{1}$, Widya Mandala Catholic University, Surabaya ${ }^{2}$, STIMIK \\ AKAKOM Yogyakarta ${ }^{3}$
}

\begin{abstract}
The Sustainable Development Goals (SDGs) bring seventeen issues that have common goals to achieve equitable prosperity. In Indonesia, the government has made industry, innovation, and infrastructure as the front line of development. Economics as one of the driving forces of industry, innovation, and infrastructure is presented in a simpler form by adding technology known as Fintech. This change creates a cashless society followed by behavior change in conducting transactions and industrial management. This study uses social network analysis (SNA) focusing on the relationship patterns between human, organization, and nation. The conceptual definition in this research is the individuals in their connection by a certain kind of relationship, while the operational definition is the individuals in their connection with "Go pay, Cashless, EMoney, T-Cash, Brizzi, Tap cash, Flazz, And Dokupay" as the filters. Data monitoring was conducted during May 15 - June 15, 2019. The results indicate diffusion of innovations takes place in Indonesia with various financial technologies. The five Fintech frequently used by Indonesian people are Go pay, E-money, T-cash, Brizzi, and Flazz. According to the concept of the Diffusion of Innovation, the innovator community in Indonesia is on the islands of Java and Sumatra. The rest are spread in other regions as early adopters, early majority, late majority, and even laggards who need to be further educated to be ready to welcome the economy 4.0 .
\end{abstract}

Keywords: : SDGs, diffusion innovations, cashless society, fintech, digital marketing

\section{Introduction}

In 2015, the Sustainable Development Goals (SDGs) were recognized as part of the Resolution of the United Nations (UN), which highlights aspects of human development and earth sustainability. Countries under the auspices of the United Nations are dedicated to 17 Sustainable Development Goals leading up to 2030. Seventeen objectives are: 1) poverty-free, 2) hunger free, 3) healthy and prosperous life, 4) quality education, 5) gender equality, 6) clean water and proper sanitation, 7) clean and affordable energy, 8) decent work and economic growth, 9) industry, innovation and infrastructure, 10) reduced inequality, 11) cities and sustainable communities, 12) responsible consumption and production, 13) climate change management 14) marine ecosystems, 15) terrestrial ecosystems, 16) peace, justice and resilient institutions, 17) goals-based partnerships [1].

Indonesia, as part of the global community, participated in the global commitment by issuing Government Regulation (PP) No. 59 of 2017 on the implementation of the Sustainable Development Goals. In this Regulation, the Government aligns global targets with national targets and appoints implementing agencies to ensure that targets can be properly 
implemented. Article 2 of the PP stipulates that Indonesia's Sustainable Development Goals are to maintain an increase in the economic prosperity of the community in a sustainable manner, preserve the sustainability of the social life of the community, sustain the quality of the environment as well as inclusive development, and maintain the improvement of the quality of life from one generation to next generation. Thus, the economic side is very instrumental in achieving these goals. This economic point refers to the eighth objective of the SDGs, namely Decent Work and Economic Growth.

\subsection{Financial Technology as a Supporter of Indonesia's Economic Growth.}

One of the contributions of the Indonesian government to achieving the SDGs from an economic point of view is to pay attention to the banking and monetary kites that can reach all groups. To realize this, finance and banking must synergize with existing technology. The emergence of financial technology (Fintech) in our nation in latest years can be a means of expanding financial services and promoting economic growth in Indonesia, which has a diverse geographical structure. The presence of Fintech makes it easier for the public to access financial products, facilitates transactions and also increases financial literacy. Cited from kominfo.go.id, the quantity of electronic money transactions in November 2015 was 46, 75 million or 78, 78\% higher in November 2014. In line with the goals of the SDGs, the Fintech, which has been created, not only provides equitable access to the banking, insurance and financial services, but it also realizes sustainable economic growth, enhances economic productivity and increased resource efficiency in terms of consumption and production.

The accomplishment of the SDGs is distinct in each nation. The presence of social and economic inequalities among individuals in a nation has become one of the variables that have not yet fully accomplished the Sustainable Development Goals. Partnerships are required to reinforce and accelerate the accomplishment of these objectives. Partnerships can be realized by encouraging Fintech to collaborate with the banking and non-banking industries. Partnerships can be realized by promoting Fintech to collaborate with the banking and nonbanking industries. The Speaker of the DPR, Bambang Soesatyo [2] stated that Indonesia was very committed to the implementation of SDGs, in line with the focus of government policy in realizing inclusive and sustainable development.

\subsection{Cashless Society impact}

The massive use of Fintech by the community will have a social impact. A fundamental change is to create a cashless society followed by changes in behavior in conducting transactions and financial management. Society tends to reduce the habit of carrying large amounts of money because it is considered unsafe and impractical. Since the introduction of ATMs, m-banking, e-banking, and credit cards, banking services have undergone significant changes in transaction patterns. In connection with Fintech, which combines financial services with technology, the government requires to develop a mature infrastructure.

The internet has become a basic need to support people's behavior in the 4.0 industrial revolution. The diverse geographical location and the nature of human resources are a challenge for the government and business. Geographical location is linked to infrastructure, while human resources are related to the financial literacy. According to OJK's Director of Regulations, Licensing and Oversight (DP3F), Hendrikus Passagi in August 2018, about $75.52 \%$ of Fintech peer to peer lending debtors are in Java [3]. This means that infrastructure 
alone is not sufficient, but it needs to be supported by knowledge and skills about concepts and financial risks for the society, so that Fintech can be accepted and implemented in the territory of Indonesia. The level of financial inclusion in Indonesia is estimated to reach 51 percent, measured by the ratio of individuals who can easily access banking services and financial technology to the total population of Indonesia. The Economic Coordinating Minister, Darmin Nasution, stated that Fintech services and the digital economy are the future. It is expected that the digital economy will develop rapidly and reach all sectors, indicated by a 22 percent contribution to the global economy in 2016 [2]. The discussion in this paper will refer to communication channels that can be used to maximize the spread of Fintech in Indonesia until the end of the SDGs goal in 2030.

\subsection{Fintech Analysis with Innovation Diffusion Theory}

The diffusion theory of innovation developed by Everett M. Rogers [4] is known as a theory of innovation decision-making. This theory illustrates the concept of innovation diffusion and the speed at which the social system accepts new ideas offered by innovation. Rogers emphasized the persuasive aspects of the innovation. Mastery in technology and finance is totally essential to adopt Fintech services. This socialization of knowledge is a shared responsibility between the government and industry. The mass media is currently the most effective means of communication to reach the wider community. Syahadianti and Subriadi [5] have stated that innovation will be accepted differently in society. There is an invention that can be adapted well, but there are also findings that are not popular. The acceptance process will be influenced by many factors, such as information media, the character of the existing social system, and the involvement of government and industry. Here are some categories of innovation users [6]:

1. Innovator, is the type of group that is ready and brave to try new things. This is consistent with the character of the people who use Fintech facilities in urban areas.

2. Early users: this category generates more opinions and finds out about innovation than other categories.

3. Initial majority: this group will compromise carefully before taking a decision to adopt a particular innovation.

4. Final majority: this group is more careful to adopt an innovation. They will observe the people around them before deciding to adopt an innovation.

5. Laggard, this group tends to be the last party to be a user of innovation.

According to Rogers [6], the adoption curve shows the number of innovations adopted over time. In the first year, the number of adopters is still small, and the number of adopters will rise considerably in the following year. After achieving its peak, the number of adopters will gradually decline.

\section{Research Method}

This research was conducted using the Social Network Analysis (SNA) method which focuses on the pattern of relationships between humans, organizations, or nation states [7]. The conceptual definition in this study is a group of individuals (Twitter accounts in this case) connected by certain types of relationships [8]. Data monitoring conversations on twitter were taken during May 15-15 June 2019. The data was taken from Drone Emprit Academic 
(dea.uii.ac.id). A social network is a social structure made up of individuals (or organizations) called "nodes", which are tied (connected) by one or more specific types of interdependency, such as friendship, kinship, common interest, financial exchange, dislike, sexual relationships, or relationships of beliefs, knowledge or prestige. Social network analysis views social relationships in terms of network theory consisting of nodes and ties (also called edges, links, or connections) [9].

\section{Findings and Discussion}

This research was conducted using the Social Network Analysis (SNA) method which focuses on the pattern of relationships between humans, organizations, or nation states [7]. The conceptual definition in this study is a group of individuals (Twitter accounts in this case) connected by certain types of relationships [8]. The operational definition used is individuals with the same type of relation with topics on go pay, cashless, e-money, tcash, brizzi, tapcash, flazz, dokupay as filters. Data monitoring conversations on twitter were taken during May 1515 June 2019. The data was taken from Drone Emprit Academic (dea.uii.ac.id).

The data found that the greatest number of total mentions were on May $31(15,270$ times quoted), June 8 (16,175 times quoted) and June 4, 2019 (15,945 times quoted). This reflects the strong need of the society for cashless transportation system which is expected to boost during the Lebaran holidays. The peak flow estimated by the Minister of Transportation, Budi Karya Sumadi, fell on May 31 and the peak of the Lebaran return flow, on 8-9 June 2019. However, the peak was May 25, 2019 (21, 205 times quoted). This is also parallel to the cashless transactions at BRI, which peaked at D-12 before Lebaran, as reported by the Director of Network and Services of Bank BRI, Osbal Saragi [10].

The graph shows that the top five buzzers are in the Java regions which include: DKI Jakarta, East Java, Central Java, Special Region of Yogyakarta, and Banten. The sixth is the Banten Province with the number of mentions 3.061 or the difference of 854 from Yogyakarta Special Province. The same thing is seen in the distribution of buzzers cities.

\section{Buzzer Cities}

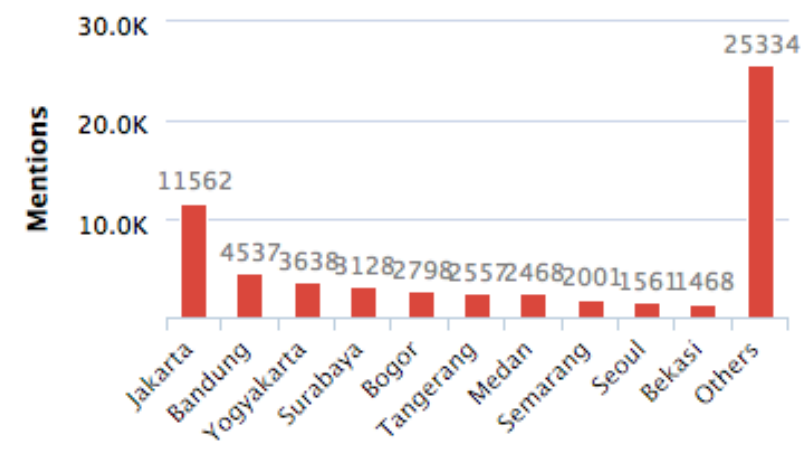

Figure 1. Top Five Buzzers Region in Java of Innovation Diffusion 
The graph shows that the top five buzzers are in the Java regions which include: DKI Jakarta, East Java, Central Java, Special Region of Yogyakarta, and Banten. The sixth is the Banten Province with the number of mentions 3.061 or the difference of 854 from Yogyakarta Special Province. The same thing is seen in the distribution of buzzers cities. Categories of innovation recipients by region in Indonesia are as follows: Innovator is Jakarta. Early adopters are Central Java, East Java, West Java. Early majority is Sumatra. Late majority are Sulawesi, Kalimantan. Laggards are Papua and several other regions in Indonesia. The last results of this study indicate diffusion of innovations takes place in Indonesia with various financial technologies, the five Fintech frequently used by Indonesian people are Go pay, Emoney, T-cash, Brizzi, and Flazz.

\section{Conclusion and Suggestion}

The results of this study indicate the five Fintech frequently used by Indonesian people are Go pay, E-money, T-cash, Brizzi, and Flazz. According to the concept of the Diffusion of Innovation, the innovator community in Indonesia is on the islands of Java and Sumatra. The rest are spread in other regions as early adopters, early majority, late majority, and even laggards who need to be further educated to be ready to welcome the economy 4.0

The growing trend of conversation data during 2018 Ramadan month indicates a strong need for electronic money. On the other side, the facts indicate that the infrastructure environment has a major impact on the need for electronic money. Based on these data, sustainable development requires the presence of other facilities to support it. Increased awareness and the need for cashless during the Ramadan holidays will not last long unless it is accompanied by various "help" facilities and "force" equipment.

\section{References}

[1] Project Everyone. 2018. Global Goal for Sustainable Development. www.globalgoals.org, date accesed: August $1^{\text {st }} 2019$.

[2] Harian Kompas, terbit tanggal 5 September 2019 halaman 5 dan 13.

[3] Validnews. 2019. Pengguna Jasa Fintech Terpusat di Jawa. https://www.validnews.id/PenggunaJasa-Fintech-Masih-Terpusat-di-Jawa-kpq.

[4] Rogers, Everet M. 1983. Diffusion of Innovations. New York: The Free Press.

[5] Syahadianti, Litafira, and Apol Pribadi Subriyadi. 2018. Diffusion of Innovation Theory Utilization Online Financial Transaction, Literature Review: International Jurnal of Economic and Financial, Issues, 2018, 8 (3), 219-226. www.econjournals.com

[6] Hafni, Z. 2011. Pengaruh Karakteristik Inovasi dan Sistem Sosial terhadap Adopsi Inovasi Program Bina Keluarga di Kelurahan Kwala Bingai Kecamatan Sabat Kabupaten Langkat. Diterbitkan oleh Repositori Institusi Universitas Sumatra Utara dalam http://repository.usu.ac.id/handle/123456789/30598

[7] Wasserman, S., and Faust, K. 1994. Social Network Analysis Method and Aplication (Vol.8). Cambridge: Cambridge University Press.

[8] Park, Han Woo. 2003. Hyperlink Network Analysis: A New Method for The Study of Social Structutr on the Web" dalam Connections. Volume 25 No.1.

[9] CreativeCommon.org. 2011. Social Network Analysis: Theory and Application. CreativeCommon. 
[10] Kumparan. 2019. Transaksi BRI di Periode Lebaram Meningkat Sebagian Besar Cashless. Kumparan Bisnis. https://kumparan.com/@kumparanbisnis/transaksi-bri-di-periode-lebaranmeningkat-sebagian-besar-cashless-1rH4qIViowi, date accesed: August $1^{\text {st }} 2019$ 